\title{
LEGALITAS ABORSI YANG DILAKUKAN OLEH ANAK AKIBAT PERKOSAAN INSES
}

\author{
Shafira Fatahaya, Rosalia Dika Agustanti \\ Fakultas Hukum Universitas Pembangunan Nasional Veteran Jakarta, Jakarta \\ shafirafatahaya@upnvj.ac.id
}

\begin{abstract}
Abstrak
Penelitian ini bertujuan untuk mengkaji mengenai legalitas aborsi yang dilakukan oleh anak korban perkosaan inses. Merujuk pada catatan Komnas Perempuan tahun 2021 telah terjadi kasus perkosaan inses terhadap perempuan sebanyak 215 kasus dimana 15 kasus terjadi pada anak. Dari perkosaan inses tidak menutup kemungkinan terjadi kehamilan pada anak dan ketidaksiapan fisik maupun psikis membuat seorang anak memilih jalan untuk aborsi. Sehingga patut dipertanyakan tentang legalitas aborsi sebagaimana Pasal 75 Ayat 2 Undang-Undang Nomor 36 Tahun 2009 tentang Kesehatan jika yang melakukan aborsi adalah anak korban perkosaan inses. Metode penelitian yang digunakan adalah metode yuridis normatif yang dilakukan dengan studi kepustakaan. Hasil penelitian menunjukkan bahwa aborsi dengan indikasi perkosaan adalah legal karena adanya trauma psikologis yang diderita oleh korban dan dimungkinkan adanya indikasi kedaruratan medis akibat perkosaan inses. Aborsi dapat dilakukan pada saat usia kehamilan tidak lebih dari 6 minggu dihitung dari awal pertama haid, namun tidak menutup kemungkinan aborsi dilakukan ketika usia kandungan melebihi batas tersebut. Sehingga penegak hukum harus dapat memastikan bahwa aborsi akibat perkosaan inses tidak dapat dituntut pidana karena telah dilindungi oleh hukum. Kepastian hukum yang ada harus dapat ditegakan agar tercipta keadilan dan kemanfaatan yang menjadi tujuan dari hukum. Selain itu, diperlukan adanya suatu edukasi mengenai kesehatan reproduksi oleh ahli kesehatan agar kasus aborsi dapat diminimalisir.
\end{abstract}

Kata kunci: Hak Anak; Legalitas Aborsi; Perkosaan Inses

\section{LEGALITY OF ABORTION PERFORMED BY CHILDREN DUE TO INCEST RAPE}

\begin{abstract}
This study aims to examine the legality of abortions performed by children of incest rape victims. Referring to the record of Komnas Perempuan in 2021 there have been cases of incest rape as many as 215 cases where 15 cases occurred in children. From incest rape does not rule out the possibility of pregnancy and physical and psychological unpreparedness that makes the child choose the path to abortion. So that the legality of abortion as Article 75 Paragraph 2 of Law No. 36 of 2009 on Health needs to be questioned if the one who performs the abortion is the child victim of incest rape. Research methods used normative juridical with literature studies. The results showed abortion with indications of rape is legal due to psychological trauma and there may be indications of medical emergencies resulting from incest rape. Abortion can be done at the gestational age of no more than 6 weeks calculated from the beginning of the first period but does not rule out the possibility of abortion when the gestational age exceeds that limit. Law enforcement must be able to ensure that abortions due to incest rape cannot be criminally prosecuted because they have been protected by law because of the existence of legal law. In addition, there is a need for an education about reproductive health by health experts so that abortion cases can be minimized.

Keywords: Rights of the Child; Legality of Abortion; Incest Rape
\end{abstract}




\section{A. PENDAHULUAN}

Anak adalah generasi penerus bangsa yang hak-haknya harus dilindungi sebagaimana yang termaktub dalam Undang-Undang Nomor 35 Tahun 2014 tentang Perubahan Atas Undang-Undang Nomor 23 Tahun 2002 tentang Perlindungan Anak (UU Perlindungan Anak) dan Undang-Undang Nomor 11 Tahun 2012 tentang Sistem Peradilan Pidana Anak (UU SPPA) yang mengatur mengenai proses penyelesaian kasus anak yang berkonflik dengan hukum memastikan bahwa meskipun anak melakukan tindak pidana namun hak mereka tetap terlindungi. Selain itu, anak juga membutuhkan orang yang lebih tua daripadanya sebagai tempat berlindung sebab mereka belum mampu menjalani kehidupannya secara mandiri. Namun, ketidakmandirian anak justru membuatnya seringkali berada dalam posisi yang terancam. Dapat dilihat dari banyaknya kasus atau berita terkait dengan anak yang menjadi korban perkosaan. Hal ini menunjukan bahwa anak sering menjadi objek pelecehan yang menyebabkan kesakitan hebat bukan hanya fisik namun juga psikis. ${ }^{1}$ Anak tidak dapat melindungi dirinya sendiri dari berbagai ancaman ${ }^{2}$ sehingga perkosaan dapat dilakukan oleh siapapun bahkan keluarga atau kerabat sendiri yang biasa disebut dengan perkosaan inses.

Komnas Perempuan mencatat bahwa pada tahun 2020 terdapat 215 kasus inses di mana 15 kasusnya menimpa anak perempuan. Meskipun jauh menurun dari tahun lalu sebanyak 822 kasus, hal ini tetap menjadi sebuah masalah masalah benar karena perkosaan inses yang terus menerus terjadi semenjak tahun 2016 (sebelumnya tidak ada). Perlu menjadi sebuah perhatian karena ternyata ayah kandung merupakan pelaku inses terbesar yaitu sebanyak 165 orang. Kasus inses merupakan kekerasan seksual yang berat karena korban menjadi tidak berdaya sebab berhadapan dengan ayah ataupun keluarganya sendiri yang tentu memungkinkan terjadinya sebuah konflik dalam keluarga misalnya perpecahan. Dalam hal ini, penyandang disabilitas dan anakanak menjadi lebih rentan untuk menjadi korban perkosaan inses karena sebuah hambatan di mana mereka belum atau tidak mampu menjelaskan tentang apa yang terjadi pada dirinya. Perkosaan inses juga biasanya baru diketahui setelah perbuatan tersebut berlangsung lama atau telah terjadi sebuah kehamilan. ${ }^{3}$

Perkosaan inses yang dilakukan oleh para pihak yang mempunyai hubungan darah dalam satu keluarga ini kemudian menjadi sebuah kejahatan yang banyak dikutuk oleh masyarakat. Bahkan dunia internasional telah mengklasifikasikan perkosaan sebagai pelanggaran hak asasi manusia (HAM) yang serius. ${ }^{4}$ HAM adalah

${ }^{1}$ Zulaeha, "Perlindungan Hukum Terhadap Anak Korban Pemerkosaan Dalam Perspektif Viktimologi," Jurnal Hukum Samudra Keadilan 10, no. 1 (2015): 125-33.

2 Anisa Cahyani, "Perlindungan Hukum Terhadap Pemberitaan Identitas Anak Korban Tindak Pidana Dalam Media Massa," JUSTITIA: Jurnal Ilmu Hukum Dan Humaniora 7, no. 2 (2020): 224-35, https://doi.org/www.dx.doi.org 10.31604/justitia.v7i1.224-225.

${ }^{3}$ Komnas Perempuan, "Perempuan Dalam Himpitan Pandemi : Lonjakan Kekerasan Seksual, Kekerasan Siber, Perkawinan Anak, Dan Keterbatasan Penanganan Ditengah Covid-19,” Catatan Tahunan, 2021.

${ }^{4}$ Angkasa Angkasa, Rili Windiasih, and Ogiandhafiz Juanda, "Efektivitas Rancangan Undang-Undang Penghapusan Kekerasan Seksual Sebagai Hukum Positif Dalam Perspektif Viktimologi," Jurnal USM Law Review 4, no. 1 (2021): 117-45, https://doi.org/http://dx.doi.org/10.26623/julr.v4i1.2696. 
hak paling mendasar yang dimiliki setiap manusia sebagai hadiah tertinggi dan paling berharga yang berikan Tuhan namun dengan mudahnnya dirampas oleh orang lain. ${ }^{5}$ Tindakan perkosaan bisa dilakukan oleh orang terdekat seperti orang tua kandung misalnya saja ayah (parental incest), kakak atau adik kandung (sibling incest) dan kerabat atau orang-orang yang mempunyai kekuasaan untuk melakukan perkosaan sedang orang tersebut masih mempunyai hubungan darah (family incest). ${ }^{6}$ Hal ini menunjukkan bahwa anak sejak usia dini berada pada situasi tidak aman, padahal keluarga mempunyai kewajiban dalam menjaga dan melindungi anak.

Kehamilan menjadi salah satu dampak dari sebuah perkosaan inses, namun kehamilan tersebut sering kali tidak diinginkan oleh korban sehingga lebih memilih jalan aborsi untuk dapat menghilangkan janin yang dikandungnya. Banyak alasan yang mendorong anak untuk melakukan aborsi (abortus provakatus), selain menutupi aib keluarga dan stigma buruk, anak yang lahir dari inses mempunyai kemungkinan cacat walaupun tidak semuanya. Cacat genetik pada anak dari hasil perkosaan inses dimungkinkan lebih besar daripada perkosaan biasa yang dapat dilihat dari beberapa keturunan hasil hubungan tersebut. ${ }^{7}$

Ketentuan dalam hukum pidana sebagaimana Pasal 346, Pasal 347, Pasal 348 dan Pasal 349 Kitab Undang-Undang Hukum Pidana (KUHP) dikatakan bahwa menghilangkan hak hidup anak dalam kandungan atau aborsi di ancam dengan pidana. Pada dasarnya, hukum masih memberikan celah atau ruang untuk seseorang melakukan aborsi namun dengan alasan yang telah ditentukan, yaitu alasan adanya indikasi medis dan anak hasil dari perkosaan sebagaimana Pasal 75 Ayat 2 UndangUndang Nomor 36 Tahun 2009 (UU Kesehatan) telah menegaskan yang kemudian dikuatkan dengan disahkan Peraturan Pemerintah Nomor 61 Tahun 2014 tentang Kesehatan Reproduksi (PP No 61 Tahun 2014). Melindungi anak sebagai korban perkosaan inses di masa depan dari rasa trauma psikologis ataupun beban sosial yang akan dihadapinya merupakan tujuan dari kesehatan itu sendiri. Pelaku aborsi akibat perkosaan inses dapat dimasukkan dalam katergori bukan perbuatan hukum sebab sebagaimana diatur dalam Pasal 48 KUHP yang menyatakan siapapun yang melakukan tindak pidana karena adanya paksaan atau kondisi mendesak (overmacht) maka orang tersebut tidak dapat dihukum.

Pada faktanya aborsi memang telah menjadi sebuah kontroversi dunia karena pandangan agama serta moral dan etika yang seringkali menjadi bahan untuk didebatkan. Aborsi menimbulkan pertanyaan mengenai hak individu yang

5 Debora Anggie Noviana, Bambang Waluyo, and Rosalia Dika. Agustanti, “Analisis Terhadap Pelaksanaan Pidana Kebiri Kimia Dalam Kasus Kekerasan Seksual Pada Anak Dalam Perspektif Yuridis Dan Kedokteran," Borneo Law Review 4, no. 1 (2020): 45-63, https://doi.org/https://doi.org/10.35334/bolrev.v4i1.1399.

${ }^{6}$ Febfitriany Kusnadi and Hery Firmansyah, "Analisis Perlindungan Hukum Terhadap Perempuan Korban Perkosaan Inses Yang Melakukan Aborsi Pada Tingkat Pemeriksaan Pengadilan (Studi Kasus Putusan Nomor 5/Pid.Sus.Anak/2018/PN. Mbn.)," Jurnal Hukum Adigama 2, no. 2 (2019): 1-23, https://doi.org/http://dx.doi.org/10.24912/adigama.v2i2.6559.

${ }^{7}$ Salim Fauzi Lubis, "Tindakan Yang Dilakukan Terhadap Kejahatan Abortus Provocatus Menurut Kitab Undang-Undang Hukum Pidana,” Jurnal Ilmu Hukum, De Lega Lata 4, no. 1 (2019): 119-30, https://doi.org/https://doi.org/10.30596/dll.v4i1.3170. 
dihubungkan dengan moralitas, agama, keluarga bahka etika seseorang. Jika membicarakan mengenai legalitas aborsi tentu kita akan berada dalam keragaman pandangan termasuk pertanyaan terkait mana yang lebih penting untuk dibela apakah keselamatan ibu yang mengandung atau hak hidup janin yang tidak berdosa. ${ }^{8}$ Menjadi lebih kompleks ketika seorang anak yang dihadapkan pada kondisi seperti itu, menjadi korban perkosaan apalagi dari keluarga terdekat sudah menjadi masalah dalam hidupnya ditambah harus menanggung beban hidup untuk mengurus anak yang dikandungnya. Di sinilah hukum harus berperan aktif untuk melindungi anak korban perkosaan inses yang melakukan aborsi sebab terdapat hak anak yang telah dirampas. Pelarangan aborsi tanpa memberikan solusi adalah suatu tindakan tidak masuk akal. Pemerintah harus memberikan penampungan bagi anak atau perempuan yang mengalami kehamilan yang bahkan mereka sendiri tidak menginginkannya, menanggung beban reproduksi dan membatasi kehamilan jika memang aborsi tidak dilegalkan. Maka untuk menghadapi kesenjangan antara aturan hukum terkait larangan aborsi dengan fenomena aborsi yang cukup serius menyebabkan hukum harus dapat bersikap adil terhadap korban perkosaan ${ }^{9}$ untuk tidak dituntut apabila aborsi menjadi jalan karena tekanan psikis yang berat.

Beberapa penelitian terdahulu, menurut Safaruddin (2016), anak yang melakukan tindak pidana erat hubungannya dengan kenakalan atau biasa disebut dengan juvenile deliquency, dimana setiap anak yang melakukan tindak pidana dan berumur 18 tahun kebawah maka sistem peradilan pidana anak yang digunakan dan penting untuk memberikan perlindungan hukum serta berbagai kepentingan terbaik anak. ${ }^{10}$ Sama halnya dengan anak pelaku aborsi yang merupakan korban dari perkosaan inses, dimana anak menanggung beban yang sangat berat jika harus melahirkan seorang anak yang bahkan dia sendiri belum bisa mengurus hidupnya. Terlebih hak anak yang dihilangkan sebab telah menjadi korban pemuas nafsu orang lain atau bahkan keluarganya sendiri.

Mufidatul (2019) dalam penelitiannya, menyatakan bahwa aborsi dapat dilegalkan sebagaimana Pasal 75 Ayat 2 Undang-Undang Nomor 36 Tahun 2009 tentang Kesehatan (UU Kesehatan) yang menegaskan dilegalkannya aborsi karena adanya trauma psikologis akibat perkosaan, karena jika diberi hukuman penjara akan berdampak luas pada korban anak perkosaan inses lainnya dan mereka semakin enggan untuk melaporkan kasus yang menimpanya karena berisiko mendapatkan

\footnotetext{
${ }^{8}$ Naomi Amadea Tumbelaka and Edward Thomas Lamury Hadjon, "Legalitas Aborsi Dalam Hukum Hak Asasi Manusia Internasional," Kertha Negara 7, no. 12 (2019): 1-16.

${ }^{9}$ Hanifta Andras Arsalna and Moh. Endriyo Susila, "Pertanggungjawaban Pidana Bagi Remaja Yang Melakukan Aborsi Karena Kehamilan Di Luar Nikah," Indonesian Journal of Criminal Law and Criminology (IJCLC) 2, no. 1 (2021): 1-11, https://doi.org/10.18196/ijclc.v2i1.11563.

${ }^{10}$ Irwan Safaruddin Harahap, "Perlindungan Hukum Terhadap Anak Korban Kejahatan Seksual Dalam Perspektif Hukum Progresif,” Jurnal Media Hukum 23, no. 1 (2016): 37-47, https://doi.org/10.18196/jmh.2015.0066.37-47.
} 
dampak negatif yang lebih besar. ${ }^{11}$ Perlu adanya pengampunan atas hukum sehingga aparat penegak hukum harus dapat melihat secara luas kemungkinan yang terjadi.

Sedangkan Mulyana (2017), dalam penelitiannya, berpendapat bahwa dalam pelaksanaannya anak pelaku tindak pidana aborsi akibat perkosaan inses harus tetap mendapat perhatian agar terhindar dari suatu praktik aborsi yang tidak aman. Hak reproduksi perempuan, hak asasi manusia janin dan ibu yang mengandung tetap yang harus dipenuhi dengan cara membuat peraturan yang lebih bijak. ${ }^{12}$ Sehingga pada dasarnya, praktik aborsi terkhusus bagi seorang anak korban perkosaan inses tidak seharusnya dijatuhkan hukuman pidana. Namun, penegakan hukum yang ada malah membuat anak menjadi posisi salah akibat tindakan aborsi yang dilakukan padahal disisi lain banyak dampak negatif yang akan diterima anak. Alasan inilah yang kemudian membuat penulisan ini menjadi menarik untuk dikaji permasalahannya secara lebih mendalam dengan lebih menitikberatkan kepada anak korban perkosaan inses dan pelaksanaan aborsi yang sebenarnya terjadi sebagai suatu pembeda dengan penelitian terdahulu.

Tujuan penelitian ini untuk memperbaharui studi terdahulu untuk membahas lebih dalam mengenai perlindungan atas hak-hak anak yang melakukan aborsi karena menjadi korban perkosaan inses dan kaitannya dengan legalitas aborsi sebagaimana Pasal 75 ayat UU Kesehatan jika yang melakukan adalah anak korban perkosaan inses tersebut. Tulisan ini didasarkan pada suatu permasalahan bahwa sudah seharusnya anak dilindungi baik pemerintah, masyarakat dan yang terpenting dari lingkup keluarga. Anak pelaku aborsi akibat perkosaan inses yang menimpanya bukan sepenuhnya kesalahan anak, dalam keadaan ini anak menanggung beban berat baik mental, fisik dan psikis serta dampak dari perkosaan inses dapat membahayakan anak yang dikandungnya seperti cacat akibat gen yang sama. Penting bagi penegak hukum untuk mempertimbangkan hal-hal dalam memutus suatu perkara anak pelaku aborsi akibat perkosaan khususnya inses mulai dari sisi keadilan dan dampak dari perbuatan ini agar hak-hak anak tetap yang menjadi alasan utama untuk tidak menjatuhkan pidana kepada anak pelaku aborsi.

\section{B. PERMASALAHAN}

Artikel ini telah merumuskan permasalahan berdasarkan uraian latar belakang yang telah dijelaskan di atas yaitu terkait dengan bagaimana legalitas mengenai aborsi dalam hukum positif bagi anak sebagai korban dari perkosaan inses?

\section{METODE PENELITIAN}

Metode penelitian yang digunakan metode yuridis normatif yang dilakukan dengan cara meneliti bahan pustaka atau data sekunder belaka. ${ }^{13}$ Penelitian hukum normatif menggunakan data sekunder yang terdiri dari bahan hukum primer, bahan

\footnotetext{
${ }^{11}$ Mufidatul Ma'sumah, "Penjatuhan Pidana Terhadap Anak Korban Perkosaan Inses Yang Melakukan Aborsi Kajian Putusan Nomor 5/PID.SUS-ANAK/2018/PN.MBN,” Komisi Yudisial 12, no. 02 (2019): 255-68, https://doi.org/http://dx.doi.org/10.29123/jy.v12i2.363.

${ }^{12}$ Aji Mulyana, "Perlindungan Hukum Terhadap Perempuan Dan Anak Akibat Tindak Pidana Abortus Provokatus Criminalis," Jurnal Wawasan Yuridika 1, no. 2 (2017): 139-54, https://doi.org/10.25072/jwy.v1i2.132.

${ }^{13}$ Soerjono Soekanto and Sri Mamudji, Penelitian Hukum Normatif (Jakarta: Rajawali Press, 2013).
} 
hukum sekunder dan bahan hukum tersier. ${ }^{14}$ Data yang digunakan diperoleh melalui data sekunder yakni bahan hukum primer seperti Undang-Undang Nomor 35 Tahun 2014 tentang Perubahan Atas Undang-Undang Nomor 23 Tahun 2002 tentang Perlindungan Anak, Undang-Undang Nomor 11 Tahun 2012 tentang Sistem Peradilan Pidana Anak, Undang-Undang Nomor 36 Tahun 2009 tentang Kesehatan, UndangUndang Nomor 1 Tahun 1946 tentang Peraturan Hukum Pidana atau Kitab UndangUndang Hukum Pidana (KUHP) dan peraturan perundang-undangan lainnya yang mendukung. Selain itu, artikel ini menggunakan bahan hukum sekunder seperti bukubuku ilmiah dan hasil penelitian peneliti terdahulu yang mengangkat masalah mengenai praktik aborsi yang dilakukan oleh korban perkosaan namun lebih memfokuskan pada perkosaan inses pada anak dibawah umur. Didukung dengan adanya wawancara yang dilakukan kepada dokter spesialis kandungan untuk menunjang dalam penelitian ini.

Pendekatan yang digunakan dalam penelitian ini adalah pendekatan undangundang (statute approach), pendekatan konseptual (conseptual approach) dan pendekatan kasus (case approach). Pendekatan peraturan perundang-undangan dilakukan dengan menelaah semua peraturan perundang-undangan dan regulasi yang bersangkut paut dengan isu hukum yang sedang ditangani. ${ }^{15}$ Selanjutnya, pendekatan konseptual beranjak dari pandangan-pandangan dan doktrin-doktrin yang berkembang di dalam ilmu hukum. Terakhir pendekatan kasus dilakukan dengan menelaah kasus yang berkaitan dengan isu hukum yang dijadikan topik pembahasan dalam sebuah penulisan. ${ }^{16}$ Penelitian ini kemudian dianalisis secara kualitatif yaitu berpijak pada norma hukum yang terdapat dalam peraturan perundang-undangan yang dianalisis dan dijabarkan sesuai dengan posisi kasus yang dijadikan sebagai pendekatan dalam penelitian. ${ }^{17}$ Data-data yang telah dikumpulkan kemudian diklasifikasikan secara sistematis untuk membuktikan adanya faktor yang menyebakan praktik aborsi menjadi perbuatan yang dilegalkan khususnya bagi korban perkosaan inses atau hubungan sedarah atau keluarga. Ketiga tahapan analisis tersebut menjadi dasar penarikan kesimpulan.

\section{HASIL DAN PEMBAHASAN}

\section{Legalitas Aborsi Bagi Anak Yang Melakukan Tindak Pidana Aborsi Akibat Perkosaan Inses}

Sebagai negara hukum, Indonesia tentu harus dapat mengedepankan hak dan kewajiban berdasarkan norma hukum yang telah diatur. Bagi mereka yang melanggar ketentuan maka sanksi yang didapatkan. Setiap pelanggaran dan kejahatan telah diatur baik di dalam maupun di luar KUHP. Pada dasarnya, tujuan dari hukum pidana sering diartikan sebagai bentuk penjatuhan sanksi pidana kepada para pelanggar hukum agar

${ }^{14}$ Soerjono Soekanto and Sri Mamudji, Penelitian Hukum Normatif, Suatu Tinjauan Singkat (Jakarta: Raja Grafindo Persada, 2006).

${ }^{15}$ Peter Mahmud Marzuki, Penelitian Hukum, Revisi (Jakarta: Prenada Media Group, 2019).

${ }^{16}$ Peter Mahmud Marzuki, Penelitian Hukum (Jakarta: Kencana, 2005).

${ }^{17}$ Zainudin Ali, Metode Penelitian Hukum (Jakarta: Sinar Grafika, 2009). 
kemudian orang tidak melakukan kejahatan. ${ }^{18}$ Permasalahan hukum akan dianggap selesai apabila si penjahat atau pelanggar telah duduk di depan meja hakim dan dijatuhi sanksi pidana. Hal itu yang memposisikan keadilan dan penegakan hukum pidana ialah terdapat sanksi pidana atau dengan kata lain sanksi pidana dijadikan sebagai sebuah barometer keadilan. ${ }^{19}$ Proses penyelesaiannya kerap kali menggunakan pidana penjara padahal hal tersebut bukanlah satu-satunya alternatif untuk mengatasi pelanggaran yang terjadi dimasyarakat.

Beberapa kasus pelanggaran hukum bahkan dimungkinkan untuk bebas dari sanksi pidana, salah satunya ialah aborsi. Aborsi atau bisa disebut dengan abortus merupakan permasalahan yang dampak begitu besar dirasakan oleh seseorang yang melakukan aborsi baik dari segi keseharan, moral dan agama. Aborsi adalah perbuatan yang dilakukan untuk menghentikan kehamilan sebelum usia kandungan kehamilan sebelum usia kandungan dua puluh minggu, dari janin kurang dari lima ratus gram dan panjang janin kurang dari dua puluh lima $\mathrm{cm}^{20}$ yang dilakukan dengan cara mengeluarkannya secara paksa, hal ini sesuai dengan kesepakatan Ikatan Dokter Indonesia (IDI). Pengguguran tersebut dapat terjadi karena dua kemungkinan yakni karena ketidaksengajaan atau alami dan dilakukan dengan suatu kesengajaan. Kesengajaan tersebut biasanya dilakukan dengan cara medis dan oleh yang ahli di bidangnya. ${ }^{21}$ Di satu sisi ada pula yang menyebut bahwa aborsi adalah suatu perbuatan membunuh nyawa manusia, melanggar hukum dan dikatakan sebagai pebuatan yang tidak berperikemanusiaan. ${ }^{22}$ Dewasa ini, pro dan kontra mengenai aborsi masih sering terdengar, bahkan KUHP sendiri menyebut aborsi sebagai sebuah tindak pidana, disisi lain aborsi masih diperlukan oleh sebagian orang dengan alasan tertentu termasuk bagi para korban perkosaan.

Perkosaan menjadi sebuah masalah besar yang menimbulkan trauma mendalam bagi korban terlebih jika harus mengandung anak hasil dari perbuatan keji yang dilakukan pelaku. Bahkan tak menutup kemungkinan perkosaan dapat dilakukan oleh keluarga atau kerabat terdekat yang mempunyai hubungan sedarah dan tak jarang korbannya adalah seorang anak, hal ini disebut dengan perkosaan inses. Menurut Kartono, inses itu sendiri merupakan hubungan seks antara laki-laki dan wanita yang mempunyai ikatan atau hubungan darah sehingga dikatakan sebagai perilaku yang menyimpang. ${ }^{23}$ Perbuatan inses merupakan penyimpangan orientasi seksual yang dapat dikatakan sama dengan homoseksual dimana perbuatan ini adalah perbuatan zina

\footnotetext{
${ }^{18}$ Marcus Priyo Gunarto, “Sikap Memidana Yang Berorientasi Pada Tujuan Pemidanaan,” Mimbar Hukum 21, no. 1 (2009): 93-108.

${ }^{19}$ Mustakim Mahmudi, "Penerapan Sanksi Pidana Anak Menurut Undang-Undang Sistem Peradilan Pidana Anak Mustakim,” Indonesia Journal of Criminal Law ( IJoCL ) 1, no. 2 (2019): 130-38. 2001).

${ }^{20}$ Goelardi Wignjosastro, Masalah Kehidupan Dan Perkembangan Janin (Jakarta: PT. Grafindo Persada,

${ }^{21}$ Ni Putu Ratih Puspitasari, I Made Sepud, and Ni Made Sukaryati Karma, "Tindak Pidana Aborsi Akibat Perkosaan," Jurnal Preferensi Hukum 2, no. 1 (2021): 135-39, https://doi.org/https://doi.org/10.22225/jph.2.1.3058.135-139.

${ }^{22}$ Waluyadi, Ilmu Kedokteran Kehakiman (Cirebon: Djambatan, 2005).

${ }^{23}$ Kartini Kartono, Psikologi Abnormal \& Abnormaalitas Seksual' (Jakarta: Mandar Maju, 1989).
} 
tabu yang sangat tidak bermoral serta dapat merusak tatanan keluarga. ${ }^{24}$ Menjadi sebuah masalah besar apabila kemudian terjadi sebuah kehamilan yang akhirnya menyebabkan ketidaksiapan mental, fisik bahkan ekonomi membuat anak korban perkosaan akhrinya memilih jalan untuk menggugurkan kandungannya. Sebab, anak sebenarnya tidak belum memiliki kapasitas secara penuh untuk memahami konsekuensi dari tindakan mereka dan seringkali melakukan sesuatu tanpa pertimbangan. ${ }^{25}$

Perkosaan inses dipengaruhi adanya budaya patriarki yang mendorong anak seringkali menjadi korban inses. ${ }^{26}$ Merasa memiliki anak menjadikan pendorong bahwa anak harus selalu mematuhi perintah orang tua sehingga anak juga harus berkelakuan sesuai apa yang diinginkan. Anak dituntut harus menghormati orang yang lebih tua darinya yang menyebabkan anak sangat rentan terhadap kasus inses. Kondisi ini menyebabkan anak semakin tertekan dan tidak mempunyai pilihan lain untuk menolak. Hal tersebut tentu harus dapat dipahami oleh aparat penegak hukum dalam hal menghadapi permasalahan aborsi yang dilakukan oleh anak sebagai korban perkosaan inses. Beban mental dan psikologis yang harus dipikul oleh anak membuat mereka tidak mampu untuk berpikir secara baik terkait hal-hal apa yang seharusnya dilakukan, seperti melaporkan bahwa dia diperkosa terhadap keluarga ataupun pihak yang berwenang sehingga aborsi menjadi tidak dihindari. Sebab, lebih banyak korban yang memilih diam dengan tidak menceritakan kejadian yang telah dialami. ${ }^{27}$

Secara umum pengaturan mengenai aborsi terdapat dalam Pasal 299, 346, 347, 348, dan 349 KUHP. Pasal-pasal ini secara jelas serta lugas menjelaskan mengenai larangan dengan alasan apapun untuk melaksanakan aborsi, termasuk aborsi yang dilakukan karena darurat (terpaksa) yaitu sebagai akibat dari perkosaan inses, baik bagi pelaku ataupun yang membantu melakukan aborsi. ${ }^{28}$ Oleh karena itu, apabila abortus provocatus merupakan pilihan yang harus diambil dan dilakukan oleh korban perkosaan inses, baik atas permintaan diri sendiri atau melalui bantuan orang lain atas persetujuan ataupun tanpa persetujuan yang bersangkutan, maka sesuai dengan ketentuan pidana mereka yang menjadi korban perkosaan termasuk inses, tidak dapat bebas dari jeratan hukum yang ada sehingga KUHP tidak memberikan perlindungan

${ }^{24}$ Vifi Swarianata, Bambang Sugiri, and Nurini Aprilianda, "Kriminalisasi Inses (Hubungan Seksual Sedarah) Dalam Perspektif Pembaharuan Hukum Pidana," Kumpulan Jurnal Mahasiswa Fakultas Hukum., 2016, 1-24, https://doi.org/10.19016/jcshokuriku.3.0_1.

${ }^{25}$ Muhammad Ridwan Lubis and Panca Sarjana Putra, "Pemidanaan Terhadap Anak Yang Berhadapan Dengan Hukum," Jurnal USM Law Review 4, no. 1 (2021): 226-41, https://doi.org/http://dx.doi.org/10.26623/julr.v4i1.3354.

${ }^{26}$ Rinna Dwi Lestari, "Perlindungan Hukum Perempuan Pelaku Aborsi Dari Korban Perkosaan Terhadap Ancaman Tindak Pidana Aborsi," MAGISTRA Law Review 1, no. 01 (2020): 1, https://doi.org/10.35973/malrev.v1i01.1406.

${ }^{27}$ Rina Shahriyani Shahrullah et al., "Analisis Yuridis Pengaturan Abortus Provokatus Terhadap Korban Pemerkosaan Di Indonesia," Jurnal Hukum Samudra Keadilan 15, no. 2 (2020): 251-63, https://doi.org/https://doi.org/10.33059/jhsk.v15i2.2613.

${ }^{28}$ Rini Wulandari, "Pertanggungjawaban Pidana Terhadap Pelaku Abortus Provocatus Criminalis (Tindak Pidana Aborsi)," Jurnal Rechtens 8, no. 2 (2019): 199-208, https://doi.org/10.36835/rechtens.v8i2.534. 
hukum terhadap perempuan. ${ }^{29}$ Dimana KUHP menyatakan wanita yang dengan sengaja melakukan pengguran atau mematikan kandungan atau menyuruh seseorang untuk melakukannya maka diancam dengan pidana penjara paling lama empat tahun. ${ }^{30}$

Larangan mengenai aborsi menjadi tidak benar-benar bersifat mutlak di Indonesia berdasarkan undang-undang dimana aborsi dapat dikatakan sebagai tindakan pengobatan dan terlepas dari pertanggungjawaban pidana. Pertanggungjawaban pidana adalah bisa atau tidaknya seorang dipidana. ${ }^{31}$ Untuk indikasi tertentu aborsi dibenarkan dan tidak dapat untuk dituntut ke pengadilan bila hal tersebut dilakukan agar jiwa dan kesehatan ibu yang mengandung dapat ditolong jiwa dan kesehatan ibu yang mengandung. ${ }^{32}$ Sekalipun KUHP melarang abortus provokatus tanpa kecuali, termasuk abortus provocatus medicinalis atau abortus provocatus therapeutics. Tetapi UU Kesehatan Kesehatan justru menjadi penyelemat bagi mereka yang ingin melakukan aborsi dengan indikasi tertentu, hal ini karena terdapatnya konteks hukum pidana ketika terjadi perbedaan antara perundangundangan yang umum (KUHP) dengan peraturan perundang-undangan yang khusus yakni asas lex specialis derogate lex generalis. ${ }^{33}$ Sehingga dalam hal ini UU Kesehatan yang mengatur tentang abortus provocatus medicinalis tetap dapat berlaku di Indonesia meskipun terdapat perbedaan yang signifikan mengenai rumusan aborsi yang diatur dalam KUHP. ${ }^{34}$ UU Kesehatan memang tidak dapat mencabut rumusan aborsi pada KUHP namun aturan khusus tentu akan dapat mengesampingkan atau melumpuhkannya.

Pada dasarnya aborsi merupakan perbuatan membunuh nyawa orang lain dan dikatakan sebagai perbuatan ilegal sebab anak dalam kandungan mempunyai hak untuk diberikan perlindungan yang sama oleh hukum dimana mempunyai hak untuk hidup, mempertahankan dan meningkatkan derajat kehidupannya. ${ }^{35}$ Aborsi kemudian menjadi legal ketika telah memenuhi apa yang diatur dalam Pasal 75 Ayat 2, pengecualian tersebut adalah apabila:

1) Adanya indikasi kedaruratan medis yang dapat mengancam nyawa ibu dan/atau anak, adanya penyakit turunan berat dan/atau cacat bawaan, maupun hal yang dapat mempersulit anak yang dilahirkan untuk hidup setelah lahir dan

${ }^{29}$ S Susanti, Yuli, "Perlindungan Hukum Bagi Pelaku Tindak Pidana Aborsi (Abortus Provocatus) Korban Perkosaan,” Syiar Hukum: Jurnal Ilmu Hukum 14, no. 2 (2012): 79-93, https://doi.org/10.32503/mizan.v9i1.1054.

${ }^{30}$ Lihat Pasal 346 KUHP.

${ }^{31}$ Rosalia Dika Agustanti, "Pertanggungjawaban Pidana Pelaku Tindak Pidana Perkosaan Ditinjau Dari Perspektif Moralitas," $\quad$ Rechtidee 13, no. 1 (2018): https://doi.org/https://doi.org/10.21107/ri.v13i1.3775.g2926.

${ }^{32}$ Lubis, "Tindakan Yang Dilakukan Terhadap Kejahatan Abortus Provocatus Menurut Kitab UndangUndang Hukum Pidana."

${ }^{33}$ Arrie Budhiartie, "Legalisasi Abortus Provocatus Karena Perkosaan Sebagai Implementasi Hak Asasi Perempuan (Analisis Yuridis Pasal 75 UU Nomor 36 Tahun 2009 Tentang Kesehatan)," Jurnal Penelitian Universitas Jambi Seri Humaniora 13, no. 2 (2011): 59-72.

${ }^{34}$ Rumelda Silalahi and Rasmita Luciana, "Pandangan Hukum Kesehatan Terhadap Abortus Provocatus Berdasarkan Undang-Undang Nomor 36 Tahun 2009," Jurnal Darma Agung 27, no. 3 (2019): 1082, https://doi.org/10.46930/ojsuda.v27i3.367.

${ }^{35}$ Linda Fidawaty, "Aborsi Dalam Perspektif Hak Asasi Manusia Dan Hukum Islam (Analisis Terhadap Peraturan Pemerintah No. 61 Tahun 2014 Tentang Kesehatan Reproduksi)," Al-'Adalah 14, no. 1 (2018): 107, https://doi.org/10.24042/adalah.v14i1.2930. 
2) Kehamilan akibat perkosaan yang menimbulkan trauma psikologis bagi korban perkosaan.

Tata cara pengguguran kandungan yang dapat dikatakan legal yaitu apabila aborsi dilalakukan pada saat janin yang belum berumur atau kurang dari dari 6 (enam) minggu yang dapat dihitung dari hari terakhir haid. Namun, syarat tersebut juga dapat dikecualikan bila adanya kedaruratan medis sekalipun kandungan telah mencapai ini lebih dari 6 (enam) minggu, ${ }^{36}$ sehingga dengan demikian aborsi yang melebihi batas usia kandungan sebagaimana yang telah diatur dapat tetap dilakukan. ${ }^{37} \mathrm{Hal}$ ini selaras dengan kode etik kedokteran yang tidak memberikan izin kepada dokter di Indonesia untuk melakukan aborsi tanpa adanya suatu indikasi kedaruratan medis. ${ }^{38}$ Seperti, jika ternyata dimungkinkan anak akan lahir secara cacat berat atau penyakit jantung yang sedang diderita oleh ibu yang mengandung dan akan membahayakan sekali untuk keselamatan jiwa keduanya pada waktu proses melahirkan kelak. ${ }^{39}$ Hal ini berlaku sekalipun usia kandungan bayi yang dikandung telah berusia lima bulan atau enam bulan semata-mata karena pertimbangan medis. ${ }^{40}$ UU Kesehatan juga telah menegaskan bahwa kesehatan reproduksi harus mendapat perhatian yang khusus. ${ }^{41}$

Alasan untuk melakukan tindakan aborsi baik legal maupun ilegal umumnya disebabkan karena tidak menginginkan untuk meneruskan kehamilan sampai melahirkan yang terdiri dari alasan kesehatan, alasan sosial, alasan ekonomi atau bahkan adanya keadaan darurat atau memaksa. ${ }^{42}$ Tak jarang ditemui kasus-kasus aborsi terkhusus yang dilakukan oleh korban perkosaan dengan berbagai alasan salah satunya adalah tidak siap menanggung malu jika harus melahirkan anak bukan dari hasil perkawinan yang sah. Hal itu bukan hanya dilakukan oleh perempuan dewasa tetapi bisa pula terjadi pada anak-anak yang menjadi korban dari perkosaan termasuk korban perkosaan inses. Perkosaan inses yang dilakukan jelas bertentangan dengan hak asasi manusia seorang perempuan dan anak sebab perkosaan yang menimpanya mengakibatkan luka fisik, psikis dan sosial. Dampak kekerasan itu menyebabkan trauma bagi korban yang dapat mempengaruhi kehidupan sosial seseorang dalam menjalankan kegiatan sehari-hari. ${ }^{43}$ Dampak psikologis bagi anak korban kekerasan seksual menyebabkan anak akan mengalami emosi yang tidak stabil, lebih sering diam,

${ }^{36}$ Ahmad Syakirin, "Dualisme Abortus Provocatus Dalam Perspektif Regulasi (Perundang-Undangan) Di Indonesia," Journal Al-Syakhsiyyah Journal of Law and Family Studies 3, no. 1 (2021): 1-15, https://doi.org/10.21154/syakhsiyyah.v3i1.3008.

${ }^{37}$ Lihat Pasal 76 UU Kesehatan.

${ }^{38}$ Rustam, "Analisis Yuridis Terhadap Tindakan Aborsi Dalam Perspektif Hukum Pidana Indonesia (Studi Komparatif; Undang-Undang Kesehatan, KUHP Dan HAM),” Dimensi 6, no. 3 (2017): 475-90.

39 Bilher Hutahaean and Rini Wulandari, "Pertanggungjawaban Pidana Terhadap Pelaku Abortus Provocatus Criminalis (Tindak Pidana Aborsi)," Jurnal Yudisial 6, no. 1 (2019): 199-208, https://doi.org/10.36835/rechtens.v8i2.534.

${ }^{40}$ Lily Marfuatun, “Aborsi Dalam Perspektif Medis Dan Yuridis,” Jurnal Kebidanan Dan Kesehatan 5, no. 1 (2018): 6-10.

${ }^{41}$ Muchtar Masrudi, Etika Profesi Hukum Kesehatan Perspektif Profesi Bidan Dalam Pelayanan Kebidanan Di Indonesia (Yogyakarta: Pustaka Baru Press, 2016).

${ }^{42}$ Yuke Novia Langie, "Tinjauan Yuridis Atas Aborsi Di Indonesia (Studi Kasus Di Kota Manado)," Lex Et Societatis 2, no. 2 (2014): 56, https://doi.org/https://doi.org/10.35796/les.v2i2.3991.

${ }^{43}$ Soetji Andari, "Dampak Sosial Dan Psikologi Korban Inses," Publiciana 11, no. 1 (2017): 179-86, https://doi.org/https://doi.org/10.31105/mipks.v41i2.2268. 
tidak mau bersosialisasi dengan keluarga, depresi, ketakutan, cemas, suka melamun, merasa malu dan tidak mau bermain dengan teman sebanyanya. Dampak sosial seperti anak tidak dapat melanjutkan sekolahnya lagi, tidak mau bergaul dengan lingkungan sekitar bahkan anak menjadi diasingkan oleh keluarga dan tetangga tetangga.

Perkosaan inses akan menyebabkan ketidakjelasan status anak yang nanti akan dilahirkannya nanti, sekalipun anak harus menikah tidak menutup kemungkinan terjadinya kekerasan dalam rumah tangga yang disebabkan dari ketidaksiapan seorang anak untuk membangun sebuah keluarga. Selain itu, jika dilihat dari sudut pandang kesehatan, anak yang dilahirkan dari hasil hubungan sedarah umumnya mengalami kelainan psikis (cacat mental) dan fisik seperti cacat/hidrocepalus (kepala membesar). ${ }^{44}$ Anak-anak hasil hubungan sedarah kemungkinan besar terlahir dengan biologis yang lemah bahkan dapat menyebabkan kematian, hal ini dikarenakan terdapat DNA (deoxyribonucleir acid) sama milik ayah dan ibu yang diturunkan kepada anak yang dikandung. ${ }^{45}$ Sehingga dapat dikatakan bahwa kemungkinan seorang bayi menderita cacat dari hubungan sedarah (inses) jauh lebih besar. Dampakdampak tersebutlah yang membuat anak sebagai korban kekerasan seksual takut dan terpaksa melakukan aborsi. Janin yang dikandung akibat perkosaan inses pada dasarnya memang memiliki hak untuk hidup begitu juga kepada pelaku aborsi yang sebenarnya secara fisik mampu untuk melahirkannya. Namun, yang menjadi prolematika adalah bagaimana gangguan psikologis atau trauma yang kemudian dialami anak pelaku aborsi setelah melahirkan anak tersebut. ${ }^{46}$ Alasan ini yang kemudian menjadi sebuah legalisasi aborsi sebagai impelementasi penegakan hak asasi manusia (HAM), sebab setiap orang tentu mempunyai kebebasan menentukan apa yang akan dilakukan bagi dirinya terlebih bagi perempuan korban kekerasan seksual sebagai pelaksana abortus provokatus indikasi perkosaan yang menimbulkan trauma mendalam ${ }^{47}$ atau bahkan indikasi kedaruratan medis akibat hubungan sedarah sebagaimana yang telah dipaparkan diatas.

Aborsi akibat perkosaan dalam UU Kesehatan memang legal namun pada kenyataannya masih ada kasus pelaku aborsi akibat perkosaan diberikan sanksi pidana salah satu contoh dapat ditemui pada Putusan Pengadilan Negeri Muara Bulian Nomor 5/Pid.Sus.Anak/2018/PN. Mbn yang dianggap bertentangan dengan hak anak. ${ }^{48}$ Anak dipidana 6 (enam) bulan penjara dan pelatihan kerja selama 3 (tiga) bulan karena

\footnotetext{
${ }^{44}$ Tateki Yoga Tursilarini, "Dampak Kekerasan Seksual Di Ranah Domestik Terhadap Keberlangsungan Hidup Anak," Media Informasi Penelitian Kesejahteraan Sosial 41, no. 1 (2017): 77-92, https://doi.org/https://doi.org/10.31105/mipks.v41i1.2277.

${ }^{45}$ Rindi Putri Afifah, Nindya Prasetya Wardhani, and Aura Shava Dhinda Salsabila, "Perlindungan Hukum Terhadap Hak Anak Incest Berdasarkan Hukum Negara Indonesia," Rewang Rencang: Jurnal Hukum Lex Generalis 2, no. 6 (2021): 498-509, https://doi.org/10.20961/jolsic.v8i1.48698.

${ }^{46}$ Kemal Fikar Muhammad, "Aspek Hukum Tentang Abortus Provocatus Therapeuticus Di Indonesia," Jurnal Penelitian IPTEKS 5, no. 1 (2020): 138-50, https://doi.org/https://doi.org/10.32528/ipteks.v5i1.3027.

${ }^{47}$ Kadek Jiyoti Mahayana, I Nyoman Putu Budiartha, and I Made Minggu Widyantara, "Tindak Pidana Pengguguran Kandungan Oleh Korban Perkosaan Dalam Pembaharuan Hukum Pidana Indonesia," Jurnal Konstruksi Hukum 2, no. 1 (2021): 138-43, https://doi.org/10.22225/jkh.2.1.2983.138-143.

48 Virgo Cahyadi and Parningotan Malau, "Perlindungan Hukum Terhadap Pelaku Aborsi Korban Pemerkosaan,” Justitia: Jurnal Ilmu Hukum Dan Humaniora 8, no. 1 (2021): 305-16.
} 
melakukan tindak pidana aborsi akibat dihamili oleh kakak kandungnya sendiri, dimana putusan yang dijatuhkan hakim dianggap tidak mempertimbangkan dampak dari perkosaan inses bagi anak sehingga kiranya kurang tepat jika hakim menjatuhkan pidana penjara bagi anak dibawah umur (15 tahun) dan didakwa dengan Pasal 77A ayat (1) jo. Pasal 45A Undang-Undang Nomor 35 Tahun 2014 tentang Perubahan Undang-Undang RI Nomor 23 Tahun 2002 Tentang Perlindungan Anak.

Merujuk pada Pasal 77A UU Perlindungan Anak dimana setiap orang yang melakukan aborsi dipidana penjara paling lama 10 (sepuluh tahun) dan denda paling banyak Rp1.000.000.000,00 (satu miliar rupiah) sehingga dalam hal ini anak yang melakukan aborsi dapat dipidana penjara maksimal 5 tahun. Dalam Pasal 45 undangundang tersebut dijelaskan bahwa setiap orang dilarang untuk melakukan aborsi terhadap kandungannya kecuali jika perbuatannya dilakukan dengan alasan dan mekanisme yang telah diatur dalam aturan hukum yang mengatur terkait aborsi yakni UU Kesehatan dan PP No 61 Tahun 2014.

Dalam memutuskan suatu perkara hakim tentu harus dapat menggunakan logika hukum sebagai bahan pertimbangan putusannya. Hakim dalam menjalankan tugasnya dilarang menafsirkan sesuatu lebih dari yang seharusnya padahal telah ada aturan yang mengatur secara tegas. Hal ini bukan mengunci kebebasan hakim karena mereka tetap diperkenankan untuk menafsirkan lebih luas bila memang aturan yang ada belum dapat mengakomodir secara keseluruhan. ${ }^{49}$ Hukum menjadi sebuah sarana pembaharuan di masyarakat yang tidak hanya berpatokan pada apa yang diatur dalam peraturan perundang-undangan saja, ${ }^{50}$ sehingga diperlukan suatu terobosan hukum melalui penalaran hukum atau argumentasi hukum (legal reasoning) yang dilakukan oleh hakim. Legal reasoning yang dilakukan hakim tentunya dapat melalui aspek filosofis, yuridis, sosiologis atau teologis yang mana dapat menciptakan asas kepastian hukum, keadilan dan kemanfaatan bagi pihak yang berhadapan dengan hukum. ${ }^{51}$

Suatu keputusan hukum harus dilakukan berdasarkan dasar pemikiran yang rasional artinya terdapat keterkaitan antara bagian satu dengan yang lainnya atau runtut (koheren) dan konsisten. Berpikir koheren berarti berpikir sesuai dengan kaidah berpikir yang logis dan tidak mengandung pertentangan dengan aturan hukum yang serta didasarkan pada suatu kebenaran, rasa percaya, etika serta keadilan. ${ }^{52}$ Logika dasar seperti penyimpulan langsung, deduksi dan induksi, kesesatan berpikir menjadi alat berpikir yang kemudian dapat menghasilkan suatu kebenaran hukum yang akhirnya dapat dipertanggungjawabkan oleh hakim dalam memberikan putusan. ${ }^{53}$

\footnotetext{
$49 \mathrm{Ni}$ Luh Putu Vera and Nurun Ainudin, "Logika Hukum Dan Terobosan Hukum Melalui Legal Reasoning," Jurnal Hukum Jatiswara 31, no. 1 (2016): 99-110.

${ }^{50}$ Mochtar Kusumaatmadja, Hukum, Masyarakat Dan Pembinaan Hukum Nasional (Bandung: Binacipta, 2001).

${ }^{51}$ Nur Iftitah Isnantiana, "Legal Reasoning Hakim Dalam Pengambilan Putusan Perkara Di Pengadilan," Islamadina 18, no. 2 (2017): 41-56, https://doi.org/10.30595/islamadina.v18i2.1920.

${ }^{52}$ Zainal Asikin, Mengenal Filsafat Hukum (Bandung: Pustaka Reka Cipta, 2014).

${ }^{53}$ Urbanus Ura Weruin, "Logika, Penalaran, Dan Argumentasi Hukum," Jurnal Konstitusi 14, no. 2 (2017): 374-95, https://doi.org/10.31078/jk1427.
} 
Dalam kasus anak korban perkosaan inses yang melakukan aborsi yang menjadi dasar pemidanaan adalah karena perbuatan tersebut dilakukan setelah usia kandungan lebih dari 40 hari dan tidak melalui prosedur yang dibenarkan oleh aturan hukum sehingga hakim dalam hal ini telah memutus sesuai dengan yang diatur oleh UU Kesehatan. Namun, hakim belum secara keseluruhan mempertimbangkan fakta-fakta hukum lain yang ada dalam persidangan. Perlu adanya pengaitan antara satu dengan yang lain, anak tersebut melakukan aborsi karena telah menjadi korban perkosaan inses oleh kakak kandungnya sebanyak sembilan kali. Anak tidak berani untuk memberitahukan bahwa ia hamil kepada orang tuanya karena adanya ancaman akan diusir. Pelaku merupakan seorang anak yang seharusnya dilindungi, bukan bermakna untuk selalu memaklumi perbuatan yang melawan hukum namun seorang hakim harus mampu berpikir secara logis dengan tetap memperhatikan sisi keadilan. Anak pelaku aborsi akibat perkosaan inses yang dilakukan oleh kakaknya menyembunyikan kehamilannya karena takut akan dijatuhi hukum adat dan diusir dari desa lingkungan masyarakat adat setempat karena dianggap tidak menghormati dan menaati kebiasaan adat yang ada di lingkungan anak.

Anak yang menjadi pelaku aborsi akibat perkosaan tentunya mempunyai trauma yang mendalam, terkadang anak lebih memilih bungkam karena akan membuat malu nama keluarga terlebih pada kasus perkosaan inses yang kemudian membuat anak merasa tidak berdaya (powerlessness) ${ }^{54}$ dan aborsi terkadang menjadi suatu jalan untuk dilakukan akibat kehamilan yang ditanggung anak yang menjadi korban. Namun, perlu ditegaskan anak korban perkosaan inses yang melakukan aborsi tetap mempunyai hak yang sama yang harus dilindungi dan mendapatkan perlakuan yang sama di hadapan hukum. Setiap pelanggaran hukum yang dituduhkan padanya serta dampak yang dialami oleh anak kiranya mendapat perlindungan dari hukum yang diperlukan sesuai dengan asas hukum. Sebab, bukan menjadi suatu yang asing ketika banyak kasus perkosaan dimana pihak korban diabaikan haknya oleh hukum. Karena diabaikan hak-haknya korban perkosaan menjadi malu dan merasa takut jika kehamilannya diketahui dan menjadi aib dilingkungan masyarakat sehingga tak jarang kehamilan akibat perkosaan selalu disembunyikan sehingga tindakan ini dapat terjadi pada korban perkosaan yang lainnya karena marasa tidak aman dan tidak dilindungi oleh hukum. ${ }^{55}$

Berbeda hal ketika putusan pengadilan negeri tersebut diajukan banding oleh panasihat hukum pelaku. Hakim pengadilan tinggi dalam Putusan Pengadilan Tinggi Jambi Nomor: 6/Pid.Sus-Anak/2018/PT JMB melakukan penalaran berdasarkan aspek yuridis yakni Pasal 75 Ayat 2 UU Kesehatan tentang Kesehatan jo. Pasal 31 PP No. 61 Tahun 2014 tentang Kesehatan Reproduksi, dimana keduanya menekankan bahwa aborsi menjadi legal bagi mereka yang hamil karena diperkosa. Kehamilan akibat perkosaan termasuk inses tentu mengakibatkan trauma sehingga perlunya adanya

\footnotetext{
${ }^{54}$ Tursilarini, "Dampak Kekerasan Seksual Di Ranah Domestik Terhadap Keberlangsungan Hidup Anak."

55 Amanda and Hetty Krisnani, "Analisis Kasus Anak Perempuan Korban Pemerkosaan Inses," Focus: Jurnal Pekerjaan Sosial 2, no. 1 (2019): 120-36, https://doi.org/10.24198/focus.v2i1.23129.
} 
perwujudan akan perlindungan khusus bagi seseorang anak pelaku tindak pidana dan khusus bagi anak korban kejahatan seksual dari tindak pidana sebagaimana dimaksudkan oleh UU Perlindungan Anak. ${ }^{56}$ Perlindungan khusus dalam hal ini diperlukan karena anak pelaku aborsi berada dalam situasi dan kondisi yang membuat dirinya hidup dalam rasa tidak aman dan penuh ancaman akibat perkosaan yang membahayakan tumbuh kembang seorang anak. Guncangan jiwa dan pengaruh psikis yang berat tentu dihadap oleh korban perkosaan inses sehingga membuat korban acapkali melakukan sebuah tindakan bodoh untuk melakukan aborsi, hal itu tentu harus menjadi pertimbangan hakim dalam memutus perkara serupa. Sebab, tidak dapat dipungkiri bahwa menempatkan anak pelaku aborsi yang merupakan korban dari perkosaan inses di dalam proses peradilan formal akan memberi efek buruk bagi perkembangan dan kehidupan anak. ${ }^{57}$

Hakim dalam memutus perkara anak sebagai pelaku aborsi harus cermat dan mempertimbangan bukan hanya dari aspek yuridis namun juga non-yuridis. Hakim harus bisa melihat penyebab anak melakukan perbuatan dan dampak yang akan ditimbulkan kedepannya apabila harus menjatuhkan pidana penjara bagi anak bukan menghakimi dengan alasan balas dendam atau penegakan keadilan namun tidak memikirkan masa depan anak. Anak pelaku aborsi akibat perkosaan inses tentu mempunyai dampak atau efek negatif yang ditanggungnya terlebih psikisosial yang tidak baik. Anak usia tersebut ada dalam tahap yang terbilang krusial dalam perkembangan kognisi, fisik maupun mentalnya. ${ }^{58}$ Sehingga proses penalaran hakim pengadilan tinggi untuk dapat memutus tindak pidana aborsi yang dilakukan oleh anak korban perkosaan inses tidak hanya terbatas pada usia kandungan dilakukannya aborsi yang diatur pada Pasal 76 UU Kesehatan namun juga didasarkan pada pemikiran hakim yang bersumber dari realitas sosial permasalahan tersebut untuk dituangkan dalam pertimbangan hukum (ratio decidendi). ${ }^{59}$ Dengan demikian dapat dikatakan bahwa putusan hakim pada pengadilan tinggi sudah tepat untuk membebas anak pelaku aborsi akibat perkosaan dalam tuntutan hukum dan memproses terkait pemulihan hak anak sesuai dengan peraturan perundang-undangan yang berlaku. ${ }^{60}$

Dari contoh kasus diatas ditinjau dari UU Kesehatan beserta dengan logika hakim dalam melakukan penalaran hukum, maka aborsi yang dilakukan oleh korban perkosaan termasuk inses dilegalkan oleh hukum. Hal ini didukung dengan adanya PP No. 61 Tahun 2014 yang dibuat sebagai aturan khusus pelaksana dari UU Kesehatan pada Pasal 75 Ayat (2) terkait dengan pengecualian aborsi atas indikasi kedaruratan

\footnotetext{
${ }^{56}$ Lihat Pasal 15 huruf e Undang-Undang Republik Indonesia Nomor 35 Tahun 2014.

${ }^{57}$ Beniharmoni Harefa, "Diversi Sebagai Perlindungan Hukum Terhadap Hak Asasi Anak Dalam Sistem Peradilan Pidana Anak Di Indonesia," Jurnal Komunikasi Hukum (JKH) 1, no. 1 (2015): 1-13, https://doi.org/10.23887/jkh.v1i1.5009.

${ }^{58}$ Yulie Echa Savitri and Maulana Rezi Ramadhana, "Pola Komunikasi Dalam Penerapan Fungsi Keluarga Pada Anak Pelaku Tindak Aborsi Di Jakarta Pusat," Linimasa: Jurnal Ilmu Komunikasi 3, no. 2 (2020): 67-79, https://doi.org/http://dx.doi.org/10.23969/linimasa.v3i2.2776.

59 J. Pajar Widodo, "Penalaran Hukum Dalam Proses Mengadili Perkara Pidana Dalam Kerangka Kebebasan Hakim," Pranata Hukum 6, no. 2 (2011): 133-42.

${ }^{60}$ Lihat Pasal 1 Angka 6 UU SPPA.
} 
medis dan pemerkosaan yang menimbulkan kehamilan yang dapat mengakibatkan tekanan jiwa atau psikologis bagi korban pemerkosaan.

Berdasarkan hasil wawancara dokter spesialis kandungan Effendy Gunawan, kehamilan yang sudah terjadi sebenarnya tidak dapat dihentikan dan baiknya dipertahankan kecuali adanya indikasi medis dimana janin tidak dapat berkembang, adanya gangguan jiwa dan korban perkosaan. Tekanan psikologis yang dialami oleh perempuan dan anak karena hamil akibat pemerkosaan dapat dikatakan sebagai sebuah indikasi medis agar dapat menggugurkan kandungannya. Terlebih anak yang hamil secara fisik belum kuat dan mental yang belum dewasa bahkan bisa berisiko kanker serviks. Sehingga dalam hal ini UU Kesehatan sudah baik dalam memberikan perlindungan kepada korban perkosaan untuk dapat melakukan aborsi dengan tetap memperhatikan kesehatan ibu yang mengandung. ${ }^{61}$

Dalam pelaksanaan aborsi harus terdapat tenaga kesehatan yang berkompenten dan berwenang untuk dapat membantu melakukan pemberhentian kehamilan (abortus provocatus) sesuai tanggung jawab profesi kedokteran. ${ }^{62}$ Sebab, proses pengguran tanpa prosedur pasti sebab memungkinkan adanya risiko infeksi yang dapat membuat tekanan darah menjadi turun drastis dan mengancam jiwa (sepsis), pendarahan (hemoragi) dan cedera yang tentu tidak kecil. ${ }^{63}$

Hal ini selaras dengan apa yang disampaikan oleh Canggih Naluri Fitriyasa yang mengatakan bahwa dalam pelaksanaanya, aborsi dapat dilakukan pada usia kandungan yang tidak dibatasi dan harus melewati banyak pihak dan harus dipresentasikan kepada komite etik dan medik rumah sakit untuk kemudian disetujui atau tidak. Namun, menurutnya aborsi tidak dapat dilegalkan termasuk pada anak dan perempuan korban perkosaan kecuali pada kasus kelainan janin yang dapat menyebabkan resiko terhadap ibu yang mengandung. Alasan korban perkosaan tidak dapat melakukan aborsi karena hal tersebut bertentang dengan sumpah dokter serta tidak sesuai dengan norma agama. Sehingga pengguran kandungan dengan alasan perkosaan tidak seharusnya dilakukan. ${ }^{64}$

Perbedaan pendapat antara dokter yang berwenang melakukan aborsi memang seringkali terjadi dalam penerapannya. Ketakutan untuk membantu melakukan aborsi karena adanya suatu hukum pidana menjadi alasannya, namun pada dasarnya telah terdapat suatu kepastian hukum. Negara memang melarang aborsi, dimana larangan tersebut telah dikecualikan oleh UU Kesehatan. Kenyataannya, tindakan aborsi atas indikasi medis adalah jalan yang harus ditempuh termasuk korban perkosaan. Dimana dalam Penjelasan Umum PP No. 61 Tahun 2014 telah menyatakan seorang korban

\footnotetext{
${ }^{61}$ Hasil Wawancara dengan Dr. Effendy Gunawan Sp. OG selaku dokter spesialis kandungan di aplikasi halodoc pada tanggal 09 Oktober 2021 pukul 09.00 WIB

${ }^{62}$ Anna Maria Salamor, "Tinjauan Yuridis Pelayanan Kesehatan Terhadap Korban Abortus Provocatus Karena Pemerkosaan,” Jurnal Belo 5, no. 1 (2019): 32-45, https://doi.org/10.30598/belovol5issue1page32-45.

${ }^{63}$ Sigit Wibowo, "Hukum Aborsi Dalam Perspektif Interkonektif(Tinjauan Dari Hukum Islam Dan Hukum Positif Indonesia)," Jurnal Justiti Hukum 3, no. 1 (2018): 51-75, https://doi.org/https://doi.org/10.36805/jjih.v3i1.506.

${ }^{64}$ Hasil Wawancara dengan Dr. Canggih Naluri Fitriyasa Sp. OG selaku dokter spesialis kandungan di aplikasi halodoc pada tanggal 27 Oktober 2021 pukul 08.20 WIB
} 
perkosaan dapat mengalami penderitaan fisik, mental, dan sosial. Dimana kehamilannya akan memperburuk mental korban akibat perkosaan yang menimpanya. Ketentuan tersebut merupakan suatu kepastian hukum dan perlindungan hukum yang diberikan oleh negara terhadap korban perkosaan yang mengalami kehamilan. ${ }^{65}$ Selain melindungi korban maka negara harus melindungi para tenaga medis yang melakukan aborsi atas apa yang dinyatakan dalam UU Kesehatan. Hal ini agar terwujudnya tujuan konstitusi dalam hal pemerintah berkewajiban melindungi menyelamatkan nyawa perempuan dan melindungi masyarakat agar kesejahteraan dapat dirasakan oleh setiap warga negaranya termasuk korban perkosaan. ${ }^{66}$

\section{E. PENUTUP}

Larangan aborsi sebagaimana dimaksud pada Pasal 75 ayat 1 UU Kesehatan dapat dikecualikan terhadap kehamilan akibat perkosaan termasuk perkosaan inses yang mengakibatkan trauma psikologis bagi korban. Sehingga aborsi menjadi legal karena dalam hal ini anak berada dalam pengaruh paksa dari keluarganya, trauma dan kemungkinan anak untuk bisa lahir dengan sempurna tidak terlalu besar, yang kemungkinan akan berdampak pula pada semakin terganggunya psikis korban perkosaan inses. Jika harus berhadapan dengan hukum maka hukuman pidana pada anak harus dapat digunakan secara hati-hati sebab terdapat hak-hak anak yang dalam hal ini harus dilindungi karena telah mendapatkan perlakuan yang tidak adil dan diskriminatif secara fisik dan psikisnya akibat perkosaan inses. Dalam memberikan putusan kepada anak pelaku aborsi akibat perkosaan inses, hakim harus mencermati fakta-fakta yang ada secara serius dan teliti, mengidentifikasi faktor penyebab anak melakukan perbuatan tersebut tidak hanya berfokus pada jangka waktu seseorang dapat melakukan aborsi dan sanksi pidananya saja. Perlu adanya jaminan kepada para tenaga medis yang melakukan aborsi akibat perkosaan agar tidak dipenjara sehingga perlindungan hukum yang ada berlaku bagi para pihak yang terlibat. Edukasi kepada masyarakat juga perlu diberikan mengenai kesehatan reproduksi oleh ahli kesehatan khususnya bagi anak agar mereka sadar betapa penting kesehatan atas reproduksi yang dimilikinya agar kasus aborsi dapat diminimalisir dan tidak adanya kasus aborsi yang dilakukan secara sembarangan tanpa bantuan pihak yang berwenang. Selain itu, peneliti berharap adanya pembaharuan hukum khususnya pada tenggang waktu pengguran kandungan yang diatur dalam UU Kesehatan agar terdapat kesepahaman antara yurisprudensi dengan pelaksanaannya khususnya dalam dunia medis atau kedokteran. Sehingga tercipta suatu kepastian hukum dan keadilan yang dapat dirasakan oleh setiap orang khususnya bagi korban perkosaan.

\section{DAFTAR PUSTAKA}

Afifah, Rindi Putri, Nindya Prasetya Wardhani, and Aura Shava Dhinda Salsabila. "Perlindungan Hukum Terhadap Hak Anak Incest Berdasarkan Hukum Negara

${ }^{65}$ Lihat Penjelasan Umum PP No 61 Tahun 2014

${ }^{66}$ Rosita and Rugun Romaida Hutabarat, "Analisis Kepastian Sumber Hukum Pemidanaan Terhadap Delik Aborsi Dalam Sistem Peradilan Pidana (Studi Putusan Pengadilan Tinggi Jambi Nomor 6/PID.SUS-ANAK/2018)," Jurnal Hukum Adigama 4, no. 3 (2021): 25-48, https://doi.org/http://dx.doi.org/10.24912/adigama.v4i1.10839. 
Indonesia." Rewang Rencang: Jurnal Hukum Lex Generalis 2, no. 6 (2021): 498-509. https://doi.org/10.20961/jolsic.v8i1.48698.

Agustanti, Rosalia Dika. "Pertanggungjawaban Pidana Pelaku Tindak Pidana Perkosaan Ditinjau Dari Perspektif Moralitas.” Rechtidee 13, no. 1 (2018): 82103. https://doi.org/https://doi.org/10.21107/ri.v13i1.3775.g2926.

Ali, Zainudin. Metode Penelitian Hukum. Jakarta: Sinar Grafika, 2009.

Amanda, and Hetty Krisnani. "Analisis Kasus Anak Perempuan Korban Pemerkosaan Inses.” Focus: Jurnal Pekerjaan Sosial 2, no. 1 (2019): 120-36. https://doi.org/10.24198/focus.v2i1.23129.

Andari, Soetji. "Dampak Sosial Dan Psikologi Korban Inses." Publiciana 11, no. 1 (2017): 179-86. https://doi.org/https://doi.org/10.31105/mipks.v41i2.2268.

Angkasa, Angkasa, Rili Windiasih, and Ogiandhafiz Juanda. "Efektivitas Rancangan Undang-Undang Penghapusan Kekerasan Seksual Sebagai Hukum Positif Dalam Perspektif Viktimologi." Jurnal USM Law Review 4, no. 1 (2021): $117-$ 45. https://doi.org/http://dx.doi.org/10.26623/julr.v4i1.2696.

Arsalna, Hanifta Andras, and Moh. Endriyo Susila. "Pertanggungjawaban Pidana Bagi Remaja Yang Melakukan Aborsi Karena Kehamilan Di Luar Nikah.” Indonesian Journal of Criminal Law and Criminology (IJCLC) 2, no. 1 (2021): 1-11. https://doi.org/10.18196/ijclc.v2i1.11563.

Asikin, Zainal. Mengenal Filsafat Hukum. Bandung: Pustaka Reka Cipta, 2014.

Budhiartie, Arrie. "Legalisasi Abortus Provocatus Karena Perkosaan Sebagai Implementasi Hak Asasi Perempuan (Analisis Yuridis Pasal 75 UU Nomor 36 Tahun 2009 Tentang Kesehatan)." Jurnal Penelitian Universitas Jambi Seri Humaniora 13, no. 2 (2011): 59-72.

Cahyadi, Virgo, and Parningotan Malau. "Perlindungan Hukum Terhadap Pelaku Aborsi Korban Pemerkosaan.” Justitia: Jurnal Ilmu Hukum Dan Humaniora 8, no. 1 (2021): 305-16.

Cahyani, Anisa. "Perlindungan Hukum Terhadap Pemberitaan Identitas Anak Korban Tindak Pidana Dalam Media Massa." JUSTITIA : Jurnal Ilmu Hukum Dan Humaniora 7, no. 2 (2020): 224-35. https://doi.org/www.dx.doi.org 10.31604/justitia.v7i1.224-225.

Fidawaty, Linda. “Aborsi Dalam Perspektif Hak Asasi Manusia Dan Hukum Islam (Analisis Terhadap Peraturan Pemerintah No. 61 Tahun 2014 Tentang Kesehatan Reproduksi).” Al-'Adalah 14, no. 1 (2018): 107. https://doi.org/10.24042/adalah.v14i1.2930.

Gunarto, Marcus Priyo. "Sikap Memidana Yang Berorientasi Pada Tujuan Pemidanaan." Mimbar Hukum 21, no. 1 (2009): 93-108.

Harahap, Irwan Safaruddin. "Perlindungan Hukum Terhadap Anak Korban Kejahatan Seksual Dalam Perspektif Hukum Progresif.” Jurnal Media Hukum 23, no. 1 (2016): 37-47. https://doi.org/10.18196/jmh.2015.0066.37-47.

Harefa, Beniharmoni. "Diversi Sebagai Perlindungan Hukum Terhadap Hak Asasi Anak Dalam Sistem Peradilan Pidana Anak Di Indonesia." Jurnal Komunikasi Hukum (JKH) 1, no. 1 (2015): 1-13. https://doi.org/10.23887/jkh.v1i1.5009.

Hutahaean, Bilher, and Rini Wulandari. "Pertanggungjawaban Pidana Terhadap Pelaku Abortus Provocatus Criminalis (Tindak Pidana Aborsi)." Jurnal Yudisial 6, no. 1 (2019): 199-208. https://doi.org/10.36835/rechtens.v8i2.534. 
Kartono, Kartini. Psikologi Abnormal \& Abnormaalitas Seksual'. Jakarta: Mandar Maju, 1989.

Komnas Perempuan. "Perempuan Dalam Himpitan Pandemi : Lonjakan Kekerasan Seksual, Kekerasan Siber, Perkawinan Anak, Dan Keterbatasan Penanganan Ditengah Covid-19." Catatan Tahunan, 2021.

Kusnadi, Febfitriany, and Hery Firmansyah. "Analisis Perlindungan Hukum Terhadap Perempuan Korban Perkosaan Inses Yang Melakukan Aborsi Pada Tingkat Pemeriksaan Pengadilan (Studi Kasus Putusan Nomor 5/Pid.Sus.Anak/2018/PN. Mbn.)." Jurnal Hukum Adigama 2, no. 2 (2019): 1-23. https://doi.org/http://dx.doi.org/10.24912/adigama.v2i2.6559.

Kusumaatmadja, Mochtar. Hukum, Masyarakat Dan Pembinaan Hukum Nasional. Bandung: Binacipta, 2001.

Langie, Yuke Novia. "Tinjauan Yuridis Atas Aborsi Di Indonesia (Studi Kasus Di Kota Manado)." Lex Et Societatis 2, no. 2 (2014): 56. https://doi.org/https://doi.org/10.35796/les.v2i2.3991.

Lestari, Rinna Dwi. "Perlindungan Hukum Perempuan Pelaku Aborsi Dari Korban Perkosaan Terhadap Ancaman Tindak Pidana Aborsi." MAGISTRA Law Review 1, no. 01 (2020): 1. https://doi.org/10.35973/malrev.v1i01.1406.

Lubis, Muhammad Ridwan, and Panca Sarjana Putra. "Pemidanaan Terhadap Anak Yang Berhadapan Dengan Hukum.” Jurnal USM Law Review 4, no. 1 (2021): 226-41. https://doi.org/http://dx.doi.org/10.26623/julr.v4i1.3354.

Lubis, Salim Fauzi. "Tindakan Yang Dilakukan Terhadap Kejahatan Abortus Provocatus Menurut Kitab Undang-Undang Hukum Pidana." Jurnal Ilmu Hukum, De Lega Lata 4, no. 1 (2019): 119-30. https://doi.org/https://doi.org/10.30596/dll.v4i1.3170.

Ma'sumah, Mufidatul. "Penjatuhan Pidana Terhadap Anak Korban Perkosaan Inses Yang Melakukan Aborsi Kajian Putusan Nomor 5/PID.SUSANAK/2018/PN.MBN.” Komisi Yudisial 12, no. 02 (2019): 255-68. https://doi.org/http://dx.doi.org/10.29123/jy.v12i2.363.

Mahayana, Kadek Jiyoti, I Nyoman Putu Budiartha, and I Made Minggu Widyantara. "Tindak Pidana Pengguguran Kandungan Oleh Korban Perkosaan Dalam Pembaharuan Hukum Pidana Indonesia.” Jurnal Konstruksi Hukum 2, no. 1 (2021): 138-43. https://doi.org/10.22225/jkh.2.1.2983.138-143.

Mahmudi, Mustakim. "Penerapan Sanksi Pidana Anak Menurut Undang-Undang Sistem Peradilan Pidana Anak Mustakim." Indonesia Journal of Criminal Law ( IJoCL ) 1, no. 2 (2019): 130-38.

Marfuatun, Lily. "Aborsi Dalam Perspektif Medis Dan Yuridis." Jurnal Kebidanan Dan Kesehatan 5, no. 1 (2018): 6-10.

Marzuki, Peter Mahmud. Penelitian Hukum. Jakarta: Kencana, 2005.

—. Penelitian Hukum. Revisi. Jakarta: Prenada Media Group, 2019.

Masrudi, Muchtar. Etika Profesi Hukum Kesehatan Perspektif Profesi Bidan Dalam Pelayanan Kebidanan Di Indonesia. Yogyakarta: Pustaka Baru Press, 2016.

Muhammad, Kemal Fikar. "Aspek Hukum Tentang Abortus Provocatus Therapeuticus Di Indonesia." Jurnal Penelitian IPTEKS 5, no. 1 (2020): 138-50. https://doi.org/https://doi.org/10.32528/ipteks.v5i1.3027.

Mulyana, Aji. "Perlindungan Hukum Terhadap Perempuan Dan Anak Akibat Tindak 
Pidana Abortus Provokatus Criminalis.” Jurnal Wawasan Yuridika 1, no. 2 (2017): 139-54. https://doi.org/10.25072/jwy.v1i2.132.

Noviana, Debora Anggie, Bambang Waluyo, and Rosalia Dika. Agustanti. “Analisis Terhadap Pelaksanaan Pidana Kebiri Kimia Dalam Kasus Kekerasan Seksual Pada Anak Dalam Perspektif Yuridis Dan Kedokteran.” Borneo Law Review 4, no. 1 (2020): 45-63. https://doi.org/https://doi.org/10.35334/bolrev.v4i1.1399.

Nur Iftitah Isnantiana. "Legal Reasoning Hakim Dalam Pengambilan Putusan Perkara Di Pengadilan." Islamadina 18, no. 2 (2017): 41-56. https://doi.org/10.30595/islamadina.v18i2.1920.

Peraturan Pemerintah Republik Indonesia Nomor 61 Tahun 2014 tentang Kesehatan Republik Indonesia (Lembaran Negara Republik Indonesia Tahun 2014 Nomor 169, Tambahan Lembaran Negara Republik Indonesia Nomor 5559) (2014).

Puspitasari, Ni Putu Ratih, I Made Sepud, and Ni Made Sukaryati Karma. "Tindak Pidana Aborsi Akibat Perkosaan." Jurnal Preferensi Hukum 2, no. 1 (2021): 135-39. https://doi.org/https://doi.org/10.22225/jph.2.1.3058.135-139.

Rosita, and Rugun Romaida Hutabarat. "Analisis Kepastian Sumber Hukum Pemidanaan Terhadap Delik Aborsi Dalam Sistem Peradilan Pidana (Studi Putusan Pengadilan Tinggi Jambi Nomor 6/PID.SUS-ANAK/2018)." Jurnal Hukum Adigama 4, no. 3 (2021): 25-48. https://doi.org/http://dx.doi.org/10.24912/adigama.v4i1.10839.

Rustam. "Analisis Yuridis Terhadap Tindakan Aborsi Dalam Perspektif Hukum Pidana Indonesia (Studi Komparatif; Undang-Undang Kesehatan, KUHP Dan HAM)." Dimensi 6, no. 3 (2017): 475-90.

Salamor, Anna Maria. "Tinjauan Yuridis Pelayanan Kesehatan Terhadap Korban Abortus Provocatus Karena Pemerkosaan.” Jurnal Belo 5, no. 1 (2019): 32-45. https://doi.org/10.30598/belovol5issue1page32-45.

Savitri, Yulie Echa, and Maulana Rezi Ramadhana. "Pola Komunikasi Dalam Penerapan Fungsi Keluarga Pada Anak Pelaku Tindak Aborsi Di Jakarta Pusat." Linimasa: Jurnal Ilmu Komunikasi 3, no. 2 (2020): 67-79. https://doi.org/http://dx.doi.org/10.23969/linimasa.v3i2.2776.

Shahrullah, Rina Shahriyani, Elza Syarief, Lu Sudirman, and Tedy Surya. "Analisis Yuridis Pengaturan Abortus Provokatus Terhadap Korban Pemerkosaan Di Indonesia." Jurnal Hukum Samudra Keadilan 15, no. 2 (2020): 251-63. https://doi.org/https://doi.org/10.33059/jhsk.v15i2.2613.

Silalahi, Rumelda, and Rasmita Luciana. "Pandangan Hukum Kesehatan Terhadap Abortus Provocatus Berdasarkan Undang-Undang Nomor 36 Tahun 2009.” Jurnal Darma Agung 27, no. 3 (2019): 1082. https://doi.org/10.46930/ojsuda.v27i3.367.

Soekanto, Soerjono, and Sri Mamudji. Penelitian Hukum Normatif, Suatu Tinjauan Singkat. Jakarta: Raja Grafindo Persada, 2006.

-. Penelitian Hukum Normatif. Jakarta: Rajawali Press, 2013.

Susanti, Yuli, S. "Perlindungan Hukum Bagi Pelaku Tindak Pidana Aborsi (Abortus Provocatus) Korban Perkosaan." Syiar Hukum: Jurnal Ilmu Hukum 14, no. 2 (2012): 79-93. https://doi.org/10.32503/mizan.v9i1.1054.

Swarianata, Vifi, Bambang Sugiri, and Nurini Aprilianda. "Kriminalisasi Inses (Hubungan Seksual Sedarah) Dalam Perspektif Pembaharuan Hukum Pidana.” 
Kumpulan Jurnal Mahasiswa Fakultas Hukum., 2016, 1-24. https://doi.org/10.19016/jcshokuriku.3.0_1.

Syakirin, Ahmad. "Dualisme Abortus Provocatus Dalam Perspektif Regulasi (Perundang-Undangan) Di Indonesia." Journal Al-Syakhsiyyah Journal of Law and Family Studies 3, no. 1 (2021): 1-15. https://doi.org/10.21154/syakhsiyyah.v3i1.3008.

Tumbelaka, Naomi Amadea, and Edward Thomas Lamury Hadjon. "Legalitas Aborsi Dalam Hukum Hak Asasi Manusia Internasional." Kertha Negara 7, no. 12 (2019): 1-16.

Tursilarini, Tateki Yoga. "Dampak Kekerasan Seksual Di Ranah Domestik Terhadap Keberlangsungan Hidup Anak." Media Informasi Penelitian Kesejahteraan Sosial 41, no. 1 (2017): https://doi.org/https://doi.org/10.31105/mipks.v41i1.2277.

Undang-Undang Republik Indonesia Nomor 1 Tahun 1946 tentang Peraturan Hukum Pidana juncto Undang-Undang Nomor 73 Tahun 1958 tentang Menyatakan Berlakunya Undang-Undang Nomor 1 Tahun 1946 Republik Indonesia tentang Peraturan Hukum Pidana untuk seluruh Wilayah Republik Indonesia dan mengubah Kitab Undang-undang Hukum Pidana (Lembaran Negara Tahun 1958 Nomor 127, Tambahan Lembaran Negara Nomor 1660), sebagaimana telah diubah dan ditambah terakhir dengan Undang-Undang Nomor 4 Tahun 1976 (Lembaran Negara Tahun 1976 Nomor 26, Tambahan Lembaran Negara Nomor 3080) (1946).

Undang-Undang Republik Indonesia Nomor 11 Tahun 2012 tentang Sistem Peradilan Pidana Anak (Lembaran Negara Republik Indonesia Tahun 2012 Nomor 153, Tambahan Lembaran Negara Republik Indonesia Nomor 5332) (2012).

Undang-Undang Republik Indonesia Nomor 35 Tahun 2014 tentang Perubahan Atas Undang-Undang Nomor 23 Tahun 2002 tentang Perlindungan Anak (Lembaran Negara Republik Indonesia Tahun 2014 Nomor 297, Tambahan Lembaran Negara Republik Indonesia Nomor 5606) (2014).

Undang-Undang Republik Indonesia Nomor 36 Tahun 2009 tentang Kesehatan (Lembaran Negara Republik Indonesia Tahun 2009 Nomor 144, Tambahan Lembaran Negara Republik Indonesia Nomor 5063) (2009).

Vera, Ni Luh Putu, and Nurun Ainudin. "Logika Hukum Dan Terobosan Hukum Melalui Legal Reasoning.” Jurnal Hukum Jatiswara 31, no. 1 (2016): 99-110.

Waluyadi. Ilmu Kedokteran Kehakiman. Cirebon: Djambatan, 2005.

Weruin, Urbanus Ura. "Logika, Penalaran, Dan Argumentasi Hukum." Jurnal Konstitusi 14, no. 2 (2017): 374-95. https://doi.org/10.31078/jk1427.

Wibowo, Sigit. "Hukum Aborsi Dalam Perspektif Interkonektif (Tinjauan Dari Hukum Islam Dan Hukum Positif Indonesia)." Jurnal Justiti Hukum 3, no. 1 (2018): 51-75. https://doi.org/https://doi.org/10.36805/jjih.v3i1.506.

Widodo, J. Pajar. "Penalaran Hukum Dalam Proses Mengadili Perkara Pidana Dalam Kerangka Kebebasan Hakim.” Pranata Hukum 6, no. 2 (2011): 133-42.

Wignjosastro, Goelardi. Masalah Kehidupan Dan Perkembangan Janin. Jakarta: PT. Grafindo Persada, 2001.

Wulandari, Rini. "Pertanggungjawaban Pidana Terhadap Pelaku Abortus Provocatus Criminalis (Tindak Pidana Aborsi).” Jurnal Rechtens 8, no. 2 (2019): 199-208. 
e-ISSN : 2621-4105

https://doi.org/10.36835/rechtens.v8i2.534.

Zulaeha. "Perlindungan Hukum Terhadap Anak Korban Pemerkosaan Dalam Perspektif Viktimologi." Jurnal Hukum Samudra Keadilan 10, no. 1 (2015): 125-33. 